\title{
Mucolytic Activity of Flavonol Isolated from The Silver Fern (Pityrogramma calomelanos)
}

\author{
Suyatno Sutoyo \\ Department of Chemistry \\ Universitas Negeri Surabaya \\ Surabaya, Indonesia \\ suyatno@unesa.ac.id \\ Tukiran \\ Department of Chemistry \\ Universitas Negeri Surabaya \\ Surabaya, Indonesia
}

\author{
Nurul Hidajati \\ Department of Chemistry \\ Universitas Negeri Surabaya \\ Surabaya, Indonesia \\ Indah Kumala Sari \\ Department of Chemistry \\ Universitas Negeri Surabaya \\ Surabaya, Indonesia
}

\begin{abstract}
The aim of study is to determine the mucolytic activity of flavonol compound namely 3,5,7,3',4'pentahydroxyflavone (quercetine), isolated from acetone extract of the silver fern ( $P$. calomelanos). The mucolytic activity assay in vitro was based on the decreasing viscosity of intestinal mucus cow. The viscosity value were analyzed statistically using one way ANOVA test, followed by LSD test to determine significant differences between treatment groups. The result of mucolytic activity test showed that isolate had mucolytic activity because it showed significant differences with negative control (phosphate buffer mucus). The isolate concentration of $0.4 \%$ had mucolytic activity which is equivalent to $0.1 \%$ acetylcysteine.
\end{abstract}

Keywords-Pityrogramma calomelanos, flavonol, quercetine, mucolyic activity

\section{INTRODUCTION}

Recently respiratory diseases is one of the major problems in Indonesia because the morbidity and mortality due to them such as acute respiratory infection, bronchitis, asthma, and tuberculosis still occupy the highest level [1]. According to WHO (2017), globally there are 1 - 4 million cases of respiratory problems (18.8 million - 12 million) which are equivalent to 120 cases per 100,000 population. Most of them occur in the Southeast Asia region at $45 \%$ where Indonesia ranks second from five countries [2].

Respiratory patients are usually characterized by persistent coughing up to several weeks accompanied by mucus production [3]. Mucus consists of water (97.5\%), protein $(0.8 \%)$, other organic substances $(0.73 \%)$, and organic salts $(0.88 \%)$ [4]. Mucus produced is thick so it affects breathing. Physiologically, cilia are unable to remove mucus because it is too thick. Treatment of cough is done with mucolytic drugs that work by diluting respiratory secretions through the breakdown of mucoprotein and mucopolysaccharide threads in mucus [5]. The synthetic mucolytic drugs on the market are bromhexin, ambroxol, and acetylcysteine. Synthetic drugs such as acetylcysteine are reported to have side effects such as gastrointestinal disorders, feeling dizzy, and sweating [6].

Several studies have shown that flavonoids from plants have mucolytic activity. The ethanol extract of red betel leaves showed mucolytic activity with a concentration of $0.3 \%$ was equivalent to $0.1 \%$ acetylcysteine. Based on the phytochemical identification, it contain alkaloid, saponin, flavonoid and polyphenol [7]. The dichloromethane extract of the $C$. sakayensis ferns with a concentration of $0.6 \%$ had mucolytic activity which is equivalent to acetylcysteine $0.1 \%$. That extract is known to contain $\beta$-sitosterol and farrerol[8].

The silver fern ( $P$. calomelanos) was one of the ferns widely distributed in tropical Asia, especially Indonesia. People used this fern as the ornamental plant and phytoremediation land polluted arsenic, mercury, zink, and lead [9]. This fern had been used for traditional medicine. An infusion of the whole plant was used to increase male sexual stamina and to treat female haemorrhaging. The leaves of this fern were used externally to heal wounds and stop bleeding. An infusion was used to treat pulmonary conditions. It was also used for asthma, cough, cold, pneumonia, tuberculosis, and whooping cough. An aqueous extract was drunk or applied locally to treat venereal disease in Guyana [10].

Many flavonoids in dihydrochalcone type had been separated from the fern species in Pityrogramma genus. For examples, from $P$. triangularis had been separated 2',6',4trihydroxy-3',5'-dimethyl-4'-methoxy dihydrochalcone [11]. Previous work, we had reported secondary metabolites isolated from the acetone extract of $P$. calomelanos' aerial part, namely kaemferol and quercetine [12]. Two isolated flavonoids showed immunostimulants activity [13]. In this paper, we reported the mucolytic activity assay of quercetine. 


\section{MATERIALS AND METHODS}

\section{A. Material}

The quercetine isolate, cow intestinal mucus, phosphate buffer solution ( $\mathrm{pH}=7$ ), acetylcystein $0.1 \%$, and tween-80 (Sigma).

\section{B. Instrument}

The Ostwald viscometer, analytical balance (Advanturer Ohaus), pycnometer (Pyrex), stop watch, waterbath (memmert), beaker glass, volumeter flask, and drop pipette.

\section{Mucolytic activity assay in vitro}

\section{1) Pepraration of intestinal mucus cow}

The intestinal cow was cleared of dirt that was attached, then it was cut longitudinally and pressed slowly. Futhermore, the mucus layer was scraped slowly until clean. The collected mucus was used for mucolytic activity assay [14].

2) Pepraration of phosphate buffer mucus solution $20 \%$ $(w / w)$

The phosphate buffer mucus solution $20 \%$ (w/w) was prepared by mixing 20 parts of mucus (in weight) with a $\mathrm{pH}$ 7 buffer-phosphate solution of 80 parts (in weight) so that a total of 100 parts (in weight). The mixture was stirred until homogeneous [14].

\section{3) Pepraration of negative control solution}

The negative control solution was prepared by mixing tween-80 as much as $0.5 \%$ (w/w) of the total weight of 0.15 grams with 30 grams of phosphate buffer mucus until the total weight of 30 grams and stirred until homogeneous [14].

\section{4) Pepraration of positive control solution}

The positive control solution was prepared by mixing acetylcysteine $0.1 \%$ as much as 0.03 grams with tween- 80 as much as $0.5 \%(\mathrm{w} / \mathrm{w})$ of total weight or 0.15 gram. Then add phosphate buffer mucus solution until the total weight of 30 grams and stirred until homogeneous [14].

\section{5) Pepraration of test solution}

The test solutions were consisted of quercetine solution with concentration of $0.2 \%, 0.4 \%, 0.6 \%, 0.8 \%, 1 \%, 1.2 \%$, and $1.4 \%$. Each test solution was made by mixing isolates as much as each concentration with tween 80 as much as $0.5 \%$ (w/w) of the total weight or equal to 0.15 grams. Then added a solution of mucus-buffer phosphate until the total weight of 30 grams is obtained and stirred until homogeneous [14].

6) Mucolytic activity assay

The mucolytic activity test was carried out by measuring viscosity using the Ostwald viscometer. Negative control solution, positive control solution, and test solution incubated for 30 minutes at $37{ }^{\circ} \mathrm{C}$. Then, the test solution were inserted into the Ostwald viscometer and the density measurements using pycnometer were carried out.
Meanwhile, the viscosity is calculated by multiplying the flow time and density. The mucolytic activity of the quercetine isolate was analyzed by one-way ANOVA followed by LSD testing in the Post-Hoc analysis to determine the significance of the difference in the viscosity value between treatments. All statistical analyzes were carried out with the SPSS [14].

\section{RESULTS AND DISCUSSIONS}

The mucolytic activity test was carried out in order to determine the mucolytic activity of isolated compund. In this study the mucolytic activity test was performed on mucus of cow intestines. The mucolytic test results are presented in Table 1.

TABLE I. VISCOSITY VALUE OF TEST SOLUTION

\begin{tabular}{|l|c|c|c|c|}
\hline \multirow{2}{*}{ Test Solution } & \multicolumn{4}{|c|}{ Viscosity (cps) } \\
\cline { 2 - 5 } & I & II & III & Average \\
\hline $\begin{array}{l}\text { Negative } \\
\text { control }\end{array}$ & 13.3477 & 13.3579 & 13.3783 & 13.3613 \\
\hline $\begin{array}{l}\text { Positive } \\
\text { control }\end{array}$ & 11.7737 & 11.7529 & 11.7737 & 11.7668 \\
\hline $\begin{array}{l}\text { Isolate of } \\
0.2 \%\end{array}$ & 11.9721 & 11.9917 & 11.9721 & 11.9786 \\
\hline $\begin{array}{l}\text { Isolate of } \\
0.4 \%\end{array}$ & 11.7845 & 11.7942 & 11.7845 & 11.7877 \\
\hline $\begin{array}{l}\text { Isolate of } \\
0.6 \%\end{array}$ & 11.7472 & 11.7671 & 11.7870 & 11.7671 \\
\hline $\begin{array}{l}\text { Isolate of } \\
0.8 \%\end{array}$ & 11.6250 & 11.6049 & 11.6250 & 11.6183 \\
\hline $\begin{array}{l}\text { Isolate of } \\
1.0 \%\end{array}$ & 11.2365 & 11.2365 & 11.2671 & 11.2647 \\
\hline $\begin{array}{l}\text { Isolate of } \\
1.2 \%\end{array}$ & 10.9791 & 10.9894 & 10.9791 & 10.9825 \\
\hline $\begin{array}{l}\text { Isolate of } \\
1.4 \%\end{array}$ & 10.5278 & 10.5480 & 10.5278 & 10.5345 \\
\hline
\end{tabular}

After knowing the viscosity value of each solution, then the solution viscosity data were analyzed statistically using SPSS with a normality and homogeneity tests to determine the sample normality and homogeneity of varians, respectively. It was then analyzed using a one-way ANAVA test followed by LSD test in Post-Hoc analysis to determine the significance of viscosity differences between treatment groups. Based on the results of the normality test and homogeneity test is obtained $\mathrm{p}$ values of 0.477 and 0.455 , respectively. Because the value is more than 0.05 , it could be stated that the sample data were normally distributed and homogeneous. The analysis is then continued with the LSD test to find out which groups have different meanings as shown in Tabel 2

TABLE II. PART OF THE LSD TEST RESULTS IN EACH TREATMENT GROUP

\begin{tabular}{|c|c|c|c|}
\hline \multicolumn{2}{|c|}{ Treatment } & Probability & Conclusion \\
\hline \multirow{2}{*}{$\begin{array}{c}\text { Negative } \\
\text { control }\end{array}$} & Positive control & 0.000 & SD \\
\cline { 2 - 4 } & Isolate of $0.2-1,4 \%$ & 0.000 & SD \\
\hline \multirow{2}{*}{ Positive } & Negative control & 0.000 & SD \\
\cline { 2 - 4 } & Extract of $0.2 \%$ & 0.000 & SD \\
\hline
\end{tabular}




\begin{tabular}{|c|c|c|c|}
\hline control & Extract of $0.4 \%$ & 0.067 & NSD \\
\cline { 2 - 4 } & Extract of $0.6 \%$ & 0.976 & NSD \\
\cline { 2 - 4 } & Extract of $0.8 \%$ & 0.000 & SD \\
\cline { 2 - 4 } & Extract of $1.0 \%$ & 0.000 & SD \\
\cline { 2 - 4 } & Extract of $1.2 \%$ & 0.000 & SD \\
\cline { 2 - 4 } & Extract of $1.4 \%$ & 0.000 & SD \\
\hline
\end{tabular}

Notes: SD $=$ Significantly different, NSD $=$ Not significantly different

Based on the results of the LSD test (Table 2), it could be stated that the isolate with various concentrations gave a significant difference $(\mathrm{p}<0.05)$ and a decrease in viscosity to negative control. This showed that isolate has mucolytic activity. Furthermore, it was compared with positive controls to determine the concentrations of isolate that have mucolytic activity equivalent to acetylcysteine $0.1 \%$. The result displayed that isolate with concentrations of $0.4 \%$ and $0.6 \%$ did not show a significant difference ( $\mathrm{p}>0.05$ ) to positive control (acetylcysteine $0.1 \%$ ). From these data, it could be concluded that the isolate with concentrations of $0.4 \%$ and $0.6 \%$ have mucolytic activity equivalent to acetylcysteine $0.1 \%$.

Mucolytic activity of quercetine was caused by the existence of functional groups, namely hydroxyl group, carbonyl group and carbonyl group conjugated with double bond. These functional group could break down the mucoprotein and mucopolysaccharide threads from sputum (mucus). In mucus, there are various types of bonds between molecules. The active group of quercetine would break the disulfide bond on mucus so that it could reduce mucus viscosity. Therefore quercetine from the silver fern has the potential activity to be developed as a natural mucolytic agent.

\section{CONCLUSIONS}

The flavonoid isolate namely quercetine has mucolytic properties in the mucolytic test of cow intestinal mucus. Quercetine with concentrations of $0.4 \%$ and $0.6 \%$ has mucolytic activity which is equivalent to positive control (acetylcysteine $0.1 \%$ ).

\section{ACKNOWLEDGMENT}

We thanks the Universitas Negeri Surabaya, for financial support through the Professor Research Grant 2019.

\section{REFERENCES}

[1] Yusnabeti, R.A. Wulandari \& R. Luciana, "PM 10 and acute respiratory infection on the furniture industry workers", Makara Kesehatan. Vol.14, No. 1, pp: 25-30, 2010.

[2] Indonesian Health Ministry. National Strategis of Tuberculosis. Jakarta, 2016.

[3] T.H. Tjay \& K. Raharja, Important Medicines, Efficacy, Use, and Side Effects, $5^{\text {th }}$ Edition, Jakarta: PT Elex Media Komputindo, 2007.

[4] R.D. Frandson, Animal Anatomy and Physiology. Yogyakarta: Gadjah Mada University Press, 1993

[5] Ariani. Effect of Variation in the Ethanolic Extract of Hibiscus Rosasinensis L. in Syrup on in Vitro Mucolytic Activity, Thesis. Postgraduate Program of Gadjah Mada University, 2014.

[6] Kasahara, Medical Herb Index in Indonesia. $2^{\text {th }}$ Edition, Jakarta: Esai Indonesia, 1995.

[7] Y.N. Windriyati, A. Budiarti, I.A. Syahida, In Vitro Mucolytic Activity of Ethanol Extract of Red Betel Leaves (Piper crocotum Ruiz and Pav.) on Cow Mucosa and Identification of Chemical Constituents. Semarang: Pharmacy Faculty of Wahid Hasyim University, 2010.

[8] E. Widiarini and S. Sutoyo, "Mucolytic activity in vitro of dichloromethane extract of C. sakayensis". Proceeding of National Seminar, Department of Chemistry, Universitas Negeri Surabaya, 2016.

[9] Visoottiviseth, P., Francesconi, K., Sridokchan, W. "The potential of Thai indigenous plant spesies for the phytoremidianation of arsenic contaminated land", Eviron Pollut, Vol. 118, No. 3, pp: 453-611, 2002.

[10] Anonimous. Pityrogramma calomelanos (L) Link. (http://tropical.theferns.info/viewtropical.php?id=Pityrogramm a+calomelanos. Accessed 18 Oktober 2017).

[11] Wollenweber, E., Dietz, V.H., Schilling, G., Favre-Bonvin, J., Smith, D.M. "Flavonoids from the chemotypes of the goldback fern Pityrogramma triangularis", Phytochemistry, Vol. 24, No. 5, pp: 965-971, 1985.

[12] Sutoyo, S., Ismono, Mitarlis, Wardana, A.P. "Secondary metabolites isolated from the dichloromethane extract of silver fern (Pityrogramma calomelanos)". Research Journal of Pharmaceutical, Biological, and Chemical Sciences. Vol. 9, No. 1, pp: 566-570, 2018.

[13] Sutoyo, S., Ismono, Mitarlis, "Immunostimulat activity of flavonoid isolated from the acetone extract of silver fern (Pityrogramma calomelanos)". Advances in Engineering Reseach. Vol. 171, pp: 86-88, 2018.

[14] A. Afiyati, M. Murrukmihadi. "The effect of fraction containing alkaloids of Hibiscus flower (Hibiscus rosa-sinensis L.) red variety to mucolytic activities in vitro". Trad. Med. J. 18 (3), pp: 187-194, 2013. 